\title{
Diagnóstico laboratorial da infecção pela Chlamydia trachomatis: vantagens e desvantagens das técnicas
}

\author{
Laboratory diagnosis of Chlamydia trachomatis infection: advantages and disadvantages of the tests
}

\author{
Claudete Farina Seadi ${ }^{1,3}$ \\ Rejane Oravec ${ }^{2}$ \\ Beatriz von Poser ${ }^{3}$ \\ Vlademir V. Cantarelli ${ }^{4}$ \\ Maria Lucia Rossetti ${ }^{5}$
}

\begin{tabular}{|c|c|}
\hline & 0 \\
\hline $\begin{array}{l}\text { Chlamydia trachomatis } \\
\text { Reação em cadeia da } \\
\text { polimerase } \\
\text { Padrão ouro }\end{array}$ & $\begin{array}{l}\text { O objetivo deste artigo é revisar e comentar as vantagens e desvantagens dos diferentes tipos } \\
\text { de testes de detecção de Chlamydia trachomatis na rotina de laboratórios clínicos, com ênfase } \\
\text { nas técnicas de amplificação. A Chlamydia trachomatis é considerada a bactéria sexualmente } \\
\text { transmissível mais freqüente em países desenvolvidos e de grande impacto no sistema } \\
\text { reprodutivo das mulheres. É o agente causador de doenças do trato urogenital, } \\
\text { linfogranuloma venéreo (LGV), tracoma, conjuntivite de inclusão e pneumonia no recém- } \\
\text { nascido. Um dos fatores de risco para a infecção é a prática sexual entre adolescentes. } \\
\text { A recorrência das infecções é comum. Episódios sucessivos de infecção aumentam o risco de } \\
\text { desenvolver seqüelas e a chance de contrair a infecção pelo vírus da imunodeficiência } \\
\text { humana. O diagnóstico da infecção pela Chlamydia trachomatis ainda é crítico, devido à } \\
\text { freqüência de infecções assintomáticas. As técnicas de amplificação de ácidos nucléicos } \\
\text { permitem utilizar urina para a detecção da clamídia, simplificando a coleta. Apresentam } \\
\text { maior sensibilidade do que a cultura e do que os testes mais utilizados, como a } \\
\text { imunofluorescência direta e o enzimaimunoensaio. A cultura celular, utilizada como padrão- } \\
\text { ouro, tem especificidade de } 100 \% \text { e sensibilidade de } 70 \% \text { a } 85 \% \text {. De acordo com o Centers } \\
\text { for Disease Control (CDC), um diagnóstico é considerado definitivo quando positivo em } \\
\text { cultura ou em pelo menos dois testes não-culturais distintos. Os testes de amplificação são } \\
\text { mais dispendiosos do que os demais testes não-culturais, mas de menor custo que a cultura. }\end{array}$ \\
\hline
\end{tabular}




\section{Introdução}

A Chlamydia trachomatis é o agente causador de doenças do trato urogenital, linfogranuloma venéreo (LGV), tracoma, conjuntivite de inclusão e pneumonia no recém-nascido. O maior impacto da infecção por clamídia ocorre no sistema reprodutivo das mulheres. A recorrência das infecções é comum $(1,4,19,30)$, especialmente nos indivíduos que se infectam antes dos 20 anos (33), e a imunidade desenvolvida é parcialmente protetora, considerando-se os 15 ou mais sorotipos da C. trachomatis $(1,4)$. Episódios sucessivos de infecção aumentam o risco de se desenvolver seqüelas e a chance de se contrair a infecção pelo vírus da imunodeficiência humana $(1,16,21,35)$.

A Organização Mundial da Saúde estima que ocorram, anualmente, mais de 90 milhões de casos novos de infecções por clamídia em todo o mundo. Destes, 4 milhões ocorrem nos Estados Unidos, representando um custo de mais de US\$2,4 bilhões por ano (34). No Brasil, não há um cálculo oficial da prevalência da infecção.

Entre os testes laboratoriais disponíveis para a detecção direta da clamídia estão a cultura, a imunofluorescência direta (DFA), o enzimaimunoensaio (EIA), a sonda de DNA e as técnicas de amplificação de ácidos nucléicos que apresentam maior sensibilidade $(1,13,33,42)$. Há ainda testes de diagnóstico indireto através da pesquisa de anticorpos (Quadro).

\section{Quadro}

Metodologias laboratoriais para 0 diagnóstico direto e indireto da infecção por C. trachomatis

\section{Cultura celular}

Pesquisa de antígenos

Imunofluorescência direta (DFA)

Enzimaimunoensaio (EIA)

Pesquisa de ácidos nucléicos

Sonda de DNA

Amplificação (PCR, LCR, TMA)

Pesquisa de anticorpos

Imunofluorescência indireta (IFI)

Microimunofluorescência indireta (MIF)

Enzimaimunoensaio indireto (EIA)

\section{Infecção}

A infecção é assintomática em até $50 \%$ dos homens e em $70 \%$ das mulheres $(1,33)$. No homem, a clamídia é responsável por $30 \%$ a $50 \%$ dos casos de uretrite nãogonocócica, e, quando não-tratada, pode levar à síndrome de Reiter (1, 34, 42). Uma característica desta síndrome é a recorrência, e inclui uretrite, artrite, uveíte e, freqüentemente, lesões de pele e de membranas mucosas $(25,42)$.

Na mulher, a infecção genital pode causar salpingite, cervicite, uretrite, endometrite, doença inflamatória pélvica (DIP), infertilidade e gravidez ectópica $(1,9,15$, $25,33)$. Quando sintomática, observam-se corrimento vaginal, disúria e sangramento após as relações sexuais. A infecção se inicia usualmente pela endocérvice, podendo ocorrer na uretra e no reto, sendo incomum apenas na uretra (5\% a 30\%). Ocorre mais freqüentemente na endocérvice e na uretra, em $50 \%$ a $60 \%$ dos casos (1). A ascensão do microrganismo do trato geniturinário para o endométrio e para as trompas de Falópio pode ser causa de dor no baixo ventre e de anormalidades menstruais (44). O paradoxo em relação à infecção por clamídia é que, mesmo assintomática, pode causar severa imunopatologia tubária. Os testes de triagem para o diagnóstico e o tratamento promoveram uma redução de aproximadamente $56 \%$ na incidência de DIP (36). Múltiplos estudos $(1,9,15,33,44)$ apontam a infecção sintomática ou assintomática como associada à gravidez ectópica. A salpingite latente e não-tratada é uma importante causa de infertilidade $(1,42)$.

Em gestantes, a infecção pode causar problemas como parto precoce, morte neonatal e doença inflamatória pélvica pós-parto. A gravidez ectópica pode causar morte durante o primeiro trimestre de gravidez (15).

A infecção por exposição perinatal ocorre em aproximadamente dois terços dos recém-nascidos de mães infectadas. A transmissão ocorre durante o trabalho de parto, sendo a causa mais comum de conjuntivite de inclusão que se desenvolve dentro de duas semanas após o nascimento e, quando não-tratada, pode causar pneumonia. A profilaxia das conjuntivites em recém-nascidos expostos à infecção falha em $15 \%$ a $25 \%$ dos casos $(1,44)$. O tratamento da pneumonia pode necessitar de hospitalização prolongada, podendo deixar como seqüela uma deficiência na função pulmonar destas crianças (42).

O Centers for Disease Control (CDC) recomenda a triagem em todas as mulheres sexualmente ativas com evidência de cervicite mucopurulenta e idade inferior a 
20 anos; em mulheres com idade entre 20 e 30 anos que não utilizam preservativos regularmente e/ou que tenham trocado de parceiro nos últimos 90 dias, e em todas as mulheres com idade inferior a 30 anos atendidas em clínicas de planejamento familiar (17).

\section{Ciclo de desenvolvimento da clamídia}

A espécie Chlamydia trachomatis pertence à família Chlamydiaceae. É responsável pela etiogenia de patologias diferentes, associadas às biovariedades tracoma, linfogranuloma venéreo e infecções genitais (42). Os sorotipos podem ser classificados de acordo com as diferentes apresentações clínicas: os sorotipos A, B, Ba (está correto), C estão associados ao tracoma endêmico; L1, L2, L3 ao LGV; D, $E, F, G, H, I, J, K$ a infecções genitais e em neonatos $(1,3,42)$.

É uma bactéria imóvel, com ciclo de desenvolvimento bifásico e replicação dentro de vacúolos na célula hospedeira, formando inclusões citoplasmáticas características (3). A replicação apresenta um ciclo multimórfico e sem sincronismo de desenvolvimento. Dentro deste ciclo multimórfico ocorrem duas formas bem distintas: os corpos elementares (EB) e os corpos reticulares (RB) $(14,35)$. Os corpos elementares são a forma infecciosa, entram no endossoma da célula hospedeira, depois de penetrar através de receptores na superfície da célula epitelial suscetí- vel à clamídia (35) (Figura 1). Aproximadamente oito horas após a entrada na célula, começa a replicação por divisão binária, completando-se o ciclo dentro do endossoma. O RB é maior em tamanho e mais rico em RNA; é a forma metabólica e não-infecciosa da clamídia. Em 24 a 72 horas o $R B$ retorna à forma $E B$, formando vacúolos contendo de 100 a 1.000 EB. Quando estes vacúolos substituem quase todo o citoplasma da célula hospedeira, ocorre lise e lançamento de EB para o meio extracelular, podendo dar início a um novo ciclo de infecção (42).

Apesar de ser antigenicamente complexa, são dois os antígenos mais relacionados ao diagnóstico e à patogênese da infecção por essa bactéria. São eles: o antígeno lipopolissacarídico (LPS), mais encontrado no RB, constituído principalmente por ácido cetodeoxietanóico; e o antígeno da major outer membrane protein (Momp) (42). Os antígenos da Momp são espécie e subespécie-específicos; por isso são utilizados para a sorotipagem (caracterização realizada através de painel de anticorpos monoclonais) (35).

Essa bactéria possui restrições metabólicas, sendo incapaz de sintetizar ATP e necessitando de fonte externa de energia. A parede celular é característica de bactéria gramnegativa, mas, por ter vida intracelular obrigatória, foi originalmente considerada um vírus. Entretanto, diferentemente dos vírus, possui RNA e DNA $(3,14,35)$.

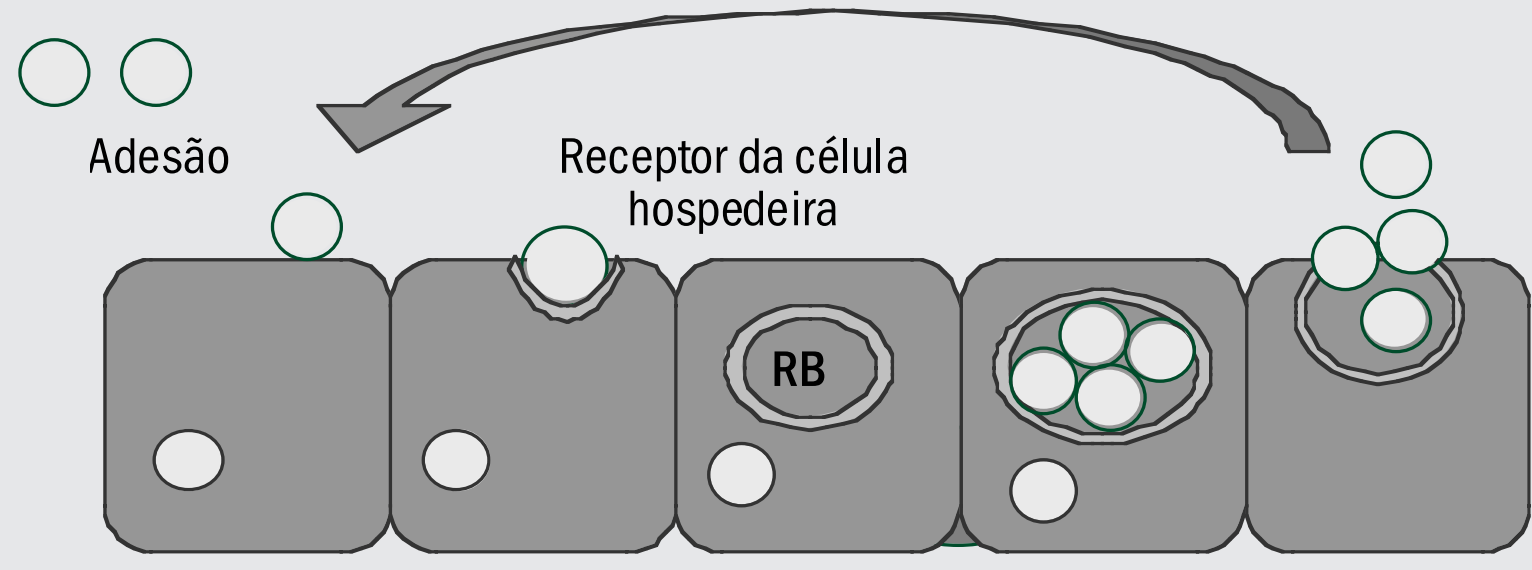

Células epiteliais da mucosa

Lise da célula urogenital 


\section{Métodos de diagnóstico laboratorial}

Independentemente do método de detecção direta em amostra clínica utilizado, a coleta adequada é essencial e se relaciona diretamente com a sensibilidade e a especificidade do teste diagnóstico $(10,18)$. O exame citológico direto por coloração de Giemsa pode ser útil no diagnóstico da conjuntivite de inclusão em recém-nascidos, mas é pouco sensível no diagnóstico da conjuntivite do adulto e de infecções do trato urogenital (35) (Tabela).

A coleta da amostra para cultura e pesquisa direta emprega tradicionalmente swab endocervical ou uretral. Os testes de amplificação permitem utilizar também amostras de urina.

Para o controle de qualidade dos testes não-culturais, o CDC recomenda (42):

1) realização de testes confirmatórios em amostras positivas de populações de baixa prevalência $(<5 \%)$ ou assintomáticas;

2) avaliação citológica periódica da qualidade da amostra;

3) não-utilização de amostras para as quais o teste não foi aprovado.

Para os testes indiretos, é recomendada especial atenção para a possibilidade de reações cruzadas interespécies da clamídia.

\section{Pesquisa de anticorpos (Ac)}

As técnicas sorológicas mais comuns, como a fixação do complemento, a imunofluorescência indireta (IFI), que utiliza células infectadas com o sorotipo $L_{2}$, e o enzimaimunoensaio heterogêneo, que utiliza antígenos recombinantes, detectam anticorpos gênero-específicos, ou seja, contra o antígeno LPS presente nos corpos elementares ou reticulares $(1,35)$.

As técnicas que permitem detectar separadamente anticorpos de classe lgG, IgA e lgM são mais úteis, embora a pesquisa de IgM seja freqüentemente indetectável quando a infecção é recorrente (35). A presença de anticorpo IgM e/ou IgA e um aumento significativo (pelo menos dois títulos) de lgG entre uma amostra colhida na fase aguda e outra na convalescente evidenciam uma infecção recente (42).

A microimunofluorescência (MIF) descrita por Wangs et al. (43) para a pesquisa de anticorpos é espécie e subespécie-específica. O princípio da técnica é o mesmo da IFI, mas difere nos antígenos, que são utilizados em quantidades mínimas, representando todas as espécies e sorotipos da clamídia (agrupados opcionalmente por afinidades). O MIF é a técnica de escolha para a pesquisa do anticorpo lgM no diagnóstico de pneumonia por clamídia no recém-nascido e a mais sensível entre as técnicas sorológicas, mas é laboriosa e de alto custo $(1,35,42)$.
Tabela

\begin{tabular}{|c|c|c|c|c|c|c|c|}
\hline & \multicolumn{3}{|c|}{ Detecção de antígeno } & \multicolumn{4}{|c|}{ Detecção de ácidos nucléicos } \\
\hline & Cultura & DFA & EIA & Sonda & PCR & LCR & TMA \\
\hline $\begin{array}{l}\text { Sensibilidade clínica } \\
\text { (Prevalência }<5 \% \text { ) }\end{array}$ & $70-85$ & 75 & $62-71$ & 75 & 90 & 87 & ND \\
\hline Especificidade clínica & 100 & 99,8 & 99,5 & 99,9 & $96-100$ & $99-100$ & $>99$ \\
\hline Material biológico & Qualquer & $\begin{array}{c}\text { END, URE, } \\
\text { OC }\end{array}$ & $\begin{array}{c}\text { END, URE, } \\
\text { OC, URIm }\end{array}$ & $\begin{array}{c}\text { END, URE, } \\
\text { OC }\end{array}$ & $\begin{array}{c}\text { END, URE, } \\
\text { OC, URI }\end{array}$ & $\begin{array}{c}\text { END, URE, } \\
\text { OC, URI }\end{array}$ & $\begin{array}{c}\text { END, URE, } \\
\text { OC, URI }\end{array}$ \\
\hline Viabilidade & S & $\mathrm{N}$ & $\mathrm{N}$ & $\mathrm{N}$ & $\mathrm{N}$ & $\mathrm{N}$ & $\mathrm{N}$ \\
\hline $\begin{array}{l}\text { Tempo de execução } \\
\text { aproximado }\end{array}$ & 48-72h & 40min. & $2-3 h$ & $2-3 h$ & $4-5 h$ & $4-5 h$ & $4-5 h$ \\
\hline Teste confirmatório & $\mathrm{N}$ & $\mathrm{N}$ & S & S & $\mathrm{N}$ & $\mathrm{N}$ & $\mathrm{N}$ \\
\hline Reação cruzada & $\mathrm{N}$ & $S$ & S & $\mathrm{N}$ & $\mathrm{N}$ & $\mathrm{N}$ & $\mathrm{N}$ \\
\hline Equipamento & $\mathrm{N}$ & $\mathrm{N}$ & S & $S$ & $S$ & $S$ & S \\
\hline Contaminação & $\mathrm{N}$ & $\mathrm{N}$ & $\mathrm{N}$ & Inibição & Inibição & Inibição & Inibição \\
\hline
\end{tabular}

Adaptado das referências 1 e 14. S = sim; N = não; ND = não-disponível; END = secreção endocervical; OC = secreção ocular; URE = secreção uretral; URI = urina; URIm = urina de pacientes do sexo masculino. 
Existem poucos estudos publicados a respeito dos enzimaimunoensaios heterogêneos indiretos e imunoeletrotransferência (1), e parecem promissores os que utilizam a heat shock protein da C. trachomatis (Chsp60) como antígeno $(38,42)$. A presença de anticorpos anti-Chsp60 está associada a um risco duas a três vezes maior de desenvolver DIP (31).

A sorologia é recomendada para estudos epidemiológicos e infecções sistêmicas, como pneumonia em recém-nascidos, LGV, salpingites, epididimites, infertilidade, gravidez ectópica, onde os títulos de anticorpo lgG são freqüentemente elevados (maiores ou iguais a 1:256, se realizados por IFI) $(35,38,42,44)$. Entretanto não é recomendada para o diagnóstico de infecções urogenitais por causa da freqüência de exposição aos sorotipos da $C$. trachomatis e pela ocorrência de reações cruzadas com outras espécies, especialmente a C. pneumoniae, tornando difícil valorizar determinações de anticorpo em uma única amostra (11). A sororreatividade em clínicas de doenças sexualmente transmissíveis é maior que $60 \%$ (35, $42,44)$, e a prevalência de Ac contra a C. pneumoniae na população dos Estados Unidos é de $50 \%$ a $70 \%$ (11). Por outro lado, em alguns indivíduos a resposta de anticorpo em infecções urogenitais é moderada ou ausente (42).

\section{Cultura}

Várias linhagens celulares permitem o cultivo da clamídia, sendo mais utilizadas as células McCoy distribuídas em monocamadas sobre microplacas. Para verificar a positividade do teste, através da presença de inclusão citoplasmática constituída de EB e RB, cora-se o tecido cultivado preferentemente com anticorpo monoclonal fluorescente. Outros métodos de visualização das inclusões podem ser utilizados, mas a DFA contribui para a maior especificidade do método $(1,28,42)$.

A vantagem da cultura é a baixa probabilidade de contaminação e a preservação do microrganismo para estudos adicionais, como o teste de suscetibilidade à terapia antimicrobiana e genotipagem (1). Devido à alta especificidade, até meados de 1998, era a única metodologia aceita para fins médico-legais em suspeita de estupro e abuso sexual, conforme recomendação do CDC. Se a cultura não for disponível, pode-se utilizar, para este fim, um teste de amplificação de ácido nucléico, desde que seja confirmado por outro teste de princípio diferente (7). Apresenta como desvantagem a necessidade de infra-estrutura de laboratório muito onerosa. Esta cultura, além disso, é trabalhosa, exige cuidados na conservação da amostra (microrganismos viáveis). Por isso, embora a especificidade seja de $100 \%$, a sensibilidade, mesmo em laboratórios de excelência, é de $80 \%(1,28)$.

A cultura tem sido considerada o padrão-ouro (gold standard), podendo, por vezes, subestimar a especificidade de outras técnicas mais sensíveis. Resultados discordantes em relação à cultura já foram até mesmo considerados falso-positivos, quando na verdade faltava sensibilidade à cultura (23). Por outro lado, avaliar testes menos sensíveis comparando-os com a cultura é superestimar a sensibilidade do teste em relação à verdadeira infecção $(1,12)$.

A agência americana Food and Drug Administration (FDA) tem ampliado a definição de um resultado verdadeiramente positivo para a infecção por clamídia, baseando-se na combinação de dois testes (cultural e não-cultural) (1). De acordo com o Guia da Prática Clínica, publicado pelo CDC, um diagnóstico é definitivo quando a cultura é positiva ou um teste não-cultural é confirmado por um segundo teste nãocultural (6). A associação de duas técnicas não-culturais positivas é aceita como padrão-ouro expandido.

\section{Pesquisa de antígenos (Ag)}

Os testes de detecção de antígenos baseiam-se na reação com os antígenos contidos no LPS e no Momp.

A visualização direta das estruturas antigênicas da clamídia, através de DFA, pode ser realizada utilizandose anticorpos monoclonais fluorescentes dirigidos aos $E B$ e RB. Além disto, a DFA possibilita avaliar simultaneamente a adequação da amostra. A DFA tem uma sensibilidade em torno de $85 \%$ e uma especificidade de $98 \%$ em relação à cultura quando ambas são realizadas em condições ótimas $(1,44)$. A desvantagem do método é a necessidade de um microscopista treinado e a dificuldade em se processar um grande número de amostras. A experiência na interpretação da imunofluorescência é fundamental, porque a ligação inespecífica do anticorpo a outros microrganismos pode ocorrer, levando a um resultado falso-positivo $(14,42)$.

A detecção direta de antígeno também pode ser realizada por testes de EIA, os quais podem variar quanto ao tipo de fase sólida (como microplacas, pérolas, tubos) onde está ligado o anticorpo primário. Quando o antígeno está presente, este reage com um anticorpo marcado com enzima, cujo produto final pode ser avaliado por espectrofotometria, fluorescência ou quimiluminescência e correlacionado com a positividade ou não do teste. 
Técnicas de EIA que empregam anticorpo anti-LPS apresentam a desvantagem de poderem resultar em reação cruzada com o LPS de outras bactérias $(1,44)$, levando a resultados falsamente positivos. São descritas reações cruzadas com bactérias gram-negativas como Acinetobacter sp., membros da família das enterobactérias, Gardnerella, neisserias e salmonelas (42). Em geral, a sensibilidade dos EIA é menor do que a cultura $(13,35)$. Um estudo comparativo de determinação de sensibilidade envolvendo cinco testes não-culturais (três EIA) em relação à cultura encontrou uma variação entre 61,9\% e 75,3\% de sensibilidade para estes testes (28). Utilizando-se o tratamento das amostras positivas com anticorpo bloqueador e obtendo-se resultado negativo para estas amostras tratadas, confirma-se o resultado positivo. A especificidade da técnica com anticorpo bloqueador é de $99,5 \%(1,42)$.

A possibilidade de o EIA ser realizado em equipamento automatizado é uma vantagem para laboratórios que processam um grande número de amostras (42).

\section{Pesquisa de ácidos nucléicos}

A partir de 1980, a tecnologia de detecção de ácidos nucléicos encontrou ampla aplicação no diagnóstico de infecção por clamídia, por ser mais rápida e sensível e por não depender da viabilidade da amostra.

Sondas de DNA com seqüência complementar ao RNA ribossomal $16 \mathrm{~S}$ do genoma da clamídia e marcadas com éster de acridina, ao hibridizar com o DNA da clamídia, são absorvidas por magnetismo, e a reação é quantificada com o uso de um luminômetro. Amostras hemolisadas são inadequadas devido ao efeito de autofluorescência, podendo produzir resultados falso-positivos (1).

A técnica da sonda de DNA é uma unidade logarítmica mais sensível do que os ElA em amostras que contêm microrganismos purificados (Figura 2) (1). Dependendo da técnica de referência utilizada, a sensibilidade pode variar entre $60 \%$ e $80 \%$, e a especificidade, entre $95 \%$ e $99 \%$ (42). Em relação aos testes de amplificação, a sensibilidade é de $77 \%$ a $93 \%$ (1).

Ao final da década de 80 , a tecnologia de amplificação de ácidos nucléicos surgiu como o mais importante avanço no diagnóstico da C. trachomatis desde que a técnica de cultura de células (in vitro) substituiu a técnica de isolamento em ovos embrionados (35).

As técnicas de amplificação detectam com rapidez pequenas quantidades de ácidos nucléicos em amostras clínicas. A amplificação de DNA ou RNA consiste na ob-

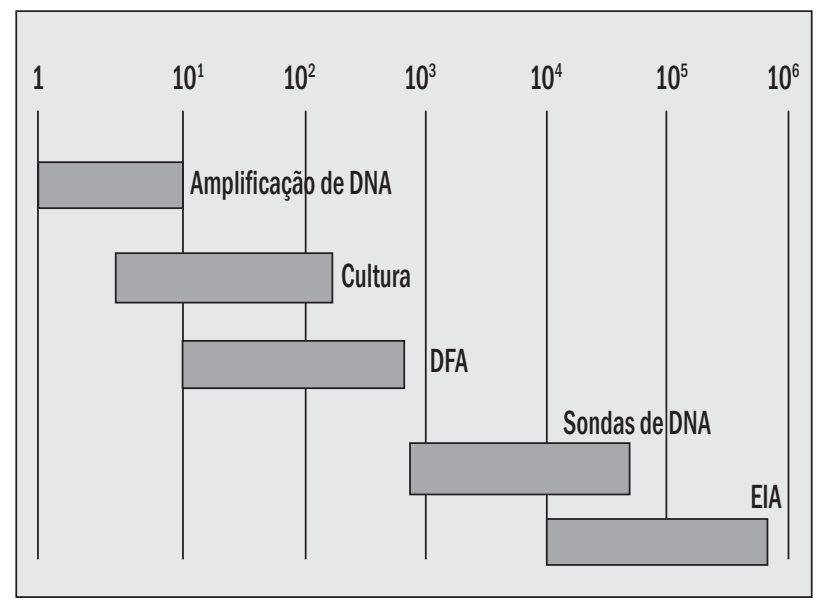

Figura 2 - Comparação dos limites de detecção do número de EB em escala logarítmica entre as diferentes tecnologias usadas no diagnóstico de C. trachomatis (adaptado de Black, Black, M.C. Current methods of laboratory diagnosis of Chlamydia trachomatis infections. Clin. Microbiol. Rev., 10(1): 160-84, 1997)

tenção de milhares de cópias de um segmento de DNA a partir de primers (iniciadores) de uma seqüência de DNAalvo. Os primers definem as regiões de DNA a serem amplificadas e a especificidade da técnica $(20,33)$.

A sensibilidade dos testes de amplificação de DNA é em torno de $20 \%$ maior do que a da cultura, da DFA e do $\operatorname{EIA}(5,13)$.

Os testes comerciais de amplificação de DNA aprovados pelo FDA são: a polymerase chain reaction (PCR) (Amplicor C. trachomatis Assay - Roche Molecular Systems), a ligase chain reaction (LCR) (LCX C. trachomatis Assay Abbott Laboratories) e o transcription-mediated amplification assay (TMA) (Gen-Probe Amplified C. trachomatis [AMP-CT] Assay), além de outros em processo de licenciamento (2). A PCR e a LCR amplificam uma seqüência de nucleotídeos do plasmídio, e a TMA é dirigida ao rRNA da clamídia. Técnicas mais sensíveis, como as de amplificação, não necessitam de EB intactos, e poucas cópias do gene são suficientes para um resultado positivo, embora existam problemas de inibição e de coleta que influenciam os resultados $(5,39)$.

A técnica que está sendo utilizada há mais tempo é a PCR (13). A seqüência do DNA da clamídia presente na amostra clínica é exposta por tratamento com detergentes ou por lise do microrganismo através de aquecimento e extraída para análise. O DNA extraído é colocado em um tubo contendo todos os reativos necessários para a reação da PCR. A reação ocorre em um termociclador, onde inicialmente a dupla hélice é desnaturada, de modo que os primers possam se hibridizar nas seqüências complementares. A enzima taq polimerase promove a adição de 
bases, compondo uma nova molécula de DNA, que serve de molde para outros ciclos de desnaturação, anelamento e extensão. Múltiplos ciclos produzirão uma amplificação logarítmica de um segmento de DNA. A detecção do DNA pode ser realizada, entre outros métodos, por eletroforese em gel de agarose a 1,5\%, com corante fluorescente, ou por captura híbrida, a qual aumenta o limite de detecção (13). A captura híbrida requer uma sonda específica de oligonucleotídeos marcada com enzima. A sonda pode estar aderida à microplaca e serve para capturar o produto da amplificação. A atividade da enzima pode ser quantificada pela leitura da densidade ótica e traduzida para um resultado positivo ou negativo.

A reação da PCR dirigida ao plasmídio da clamídia é considerada mais sensível, já que este pode conter de sete a dez cópias de DNA, enquanto a PCR dirigida ao genoma codificador Momp dispõe de uma só cópia $(1,8,40,41)$. A possibilidade de a $\mathrm{PCR}$ plasmidial não detectar amostras clínicas infectadas que perderam o plasmídio foi descrita, mas estudos comparativos entre PCR-plasmídio e PCRMomp não revelaram qualquer linhagem adicional sem plasmídio (29). A PCR-Momp (não-disponível comercialmente) tem sido utilizada como método de confirmação de resultados positivos ou discordantes $(32,37)$ e para a genotipagem.

A especificidade e a sensibilidade da técnica de PCR dependem dos primers utilizados, da técnica de referência, do tipo de material, da população a ser analisada, da preparação da amostra e do método de detecção do produto amplificado, considerando-se a presença de inibidores $(24,39)$. Para identificar a presença de inibidores na amostra é necessário introduzir-se na reação controles de amplificação $(10,13,32)$. Recursos para detectar inibição, tais como repetição da PCR em amostras diluídas (24) e reação em duplicata contaminando propositalmente uma das amostras, não são adequados para serem introduzidos na rotina de laboratórios clínicos (35).

Boas práticas de laboratório e procedimentos de desinfecção são imprescindíveis para minimizar problemas de contaminação.

Podem-se utilizar suspensões de cultura de linhagens de Chlamydia trachomatis, de Chlamydia pneumoniae e de Chlamydia psittaci, para avaliar a especificidade dos primers. A reação da PCR positiva apenas para linhagens de Chlamydia trachomatis demonstra que os primers são específicos (29).

A sensibilidade dos vários sistemas de detecção pode ser determinada pela verificação da quantidade mínima de células infectadas com as sorovariedades mais freqüentes, que em diluições seriadas obtidas de suspensões de cultura ainda produzem sinal de amplificação de DNA. Para aumentar a sensibilidade, pode-se utilizar o recurso da reação de nested PCR, que também pode ser útil como teste confirmatório do PCR plasmidial (22), porém aumenta o risco para resultado falso-positivo devido à facilidade de contaminação das reações negativas pelas positivas.

Outra importante vantagem do emprego da reação de PCR é a genotipagem, que pode ser realizada por restriction fragment length polymorphism (RFLP) ou por seqüenciamento de nucleotídeos direto da amostra clínica submetida a reações de amplificação do gene omp1, diferente da sorotipagem, que é realizada a partir de cultura seguida de aplicação de um painel de anticorpos monoclonais $(26,27)$.

O benefício da amplificação é a sensibilidade e a possibilidade de se utilizar urina para a detecção de DNA da clamídia, o que simplifica a coleta. Sua desvantagem é o custo e os problemas relacionados à inibição $(24,37)$. Embora a sensibilidade seja maior em relação a outros métodos, 5\% das amostras positivas para a cultura podem ser negativas por amplificação (35).

Os testes de amplificação são mais dispendiosos do que outros métodos não-culturais, mas de menor custo do que a cultura. A morbidade e o custo/benefício de identificar e tratar pessoas infectadas justificam a adoção do teste (5).

\section{Conclusão}

Ao longo deste artigo procurou-se sintetizar, de modo sistemático e didático, o conhecimento disponível sobre os métodos de diagnóstico laboratorial mais aplicados na prática de detecção da clamídia, revisando vantagens, desvantagens, precauções e meios de otimizar a qualidade de resultados.

Assim, por exemplo, ao abordarmos a pesquisa indireta, registramos a existência de situações em que é necessária a coleta de duas amostras em intervalos de pelo menos 15 dias, com o risco de altos percentuais de reações cruzadas pelas técnicas de EIA e de IFI. A má administração de tais limites do método compromete seus resultados.

Por outro lado, a cultura, apesar de exigir infra-estrutura pouco acessível da maioria dos laboratórios de rotina, oferece maior segurança quanto à contaminação de 
amostras. Sua sensibilidade, mesmo sendo inferior somente à da $\mathrm{PCR}$, compensa-se pela sua especificidade.

Ainda manual e subjetiva, a DFA continua sendo importante opção em nosso meio para o diagnóstico de infecção por clamídia, pois é a única tecnologia que permite avaliar a qualidade da coleta, embora necessite de investimento intensivo e rígido treinamento de microscopistas a fim de assegurar resultados confiáveis.

A EIA, tecnologia automatizada, supera em muito o aspecto trabalhoso dos demais métodos. Suas restrições são as reações cruzadas e os resultados falso-positivos. Porém a repetição do teste com o uso de anticorpo bloqueador, apesar de aumentar o custo do teste, pode assegurar resultados precisos.
Finalmente, os métodos mais completos em termos de sensibilidade e especificidade e com menores riscos são os de detecção de ácidos nucléicos, dos quais a PCR é o mais difundido, apesar de seus custos elevados.

$\mathrm{Na}$ atualidade, em nosso meio, várias dessas tecnologias, com seus riscos e benefícios, são utilizadas, tendo em vista que os métodos baseados na deteç̧ão de ácidos nucléicos são ainda inacessíveis ao laboratório de rotina por causa dos seus custos elevados.

Enquanto a melhor tecnologia não está ao alcance de todos, a ética e o senso de profissionalismo devem prevalecer no cotidiano do laboratório, refletindo a consciência sobre o quanto custa tratar conseqüências adversas e sobre a morbidade da infecção por clamídia.

\section{Referências}

I. Black, M.C. Current methods of laboratory diagnosis of Chlamydia trachomatis infections. Clin. Microbiol. Rev., IO(I): 160-84, 1997.

2. Black, M.C. et al. A. The use of molecular techniques for the diagnosis and epidemiologic study of sexually transmitted infections. Cur. Infect. Dis. Rep., 2: 31-43, 2000.

3. Barnes, C.R. Laboratory diagnosis of human chlamydial infections. Clin. Microbiol. Rev., 2(2): I 19-36, 1989.

4. Brunham, R.C. Human immunity to Chlamydiae. In: Chlamydia intracellular biology, pathogenesis, and immunity. Washington: ASM, 1999. Cap. 8, p. 211-38.

5. Caliendo, A.M.M.D. Diagnosis of Chlamydia trachomatis infection using amplification methods: can we afford it? Clin. Microbiol. News., 20(9): 75-8, 1998.

6. Centers for Disease Control and Prevention. Sexually transmitted diseases clinical practice guidelines. Atlanta Ga.: Centers for Disease Control and Prevention, 1991.

7. Centers for Disease Control and Prevention. Guidelines for treatment of sexually transmitted diseases. MMWR, 47(RR-1): 1- I 18, 1998.

8. Farrell, D.J.; Haran, M. \& Park, B. Comparasion of PCR/nucleic acid hybridization and EIA for the detection of Chlamydia trachomatis in different populations in a regional center. Pathol., 28( I ): 74-9, 1996

9. Gaydos, C. et al. Molecular amplification assays to detect chlamydial infections in urine specimens form high school female students and monitor the persistence of chlamydial DNA after therapy. J. Infect. Dis., 177: 417-24, 1998.

10. Gaydos, C. et al. Use of ligase chain reaction with urine versus cervical culture for detection of Chlamydia trachomatis in an asymptomatic military population of pregnant and nonpregnant females attending Papanicolaou smear clinics. J. Clin. Microbiol., 36(5): I300-4, 1998.

II. Grayston, J.T. Infections caused by Chlamydia pneumoniae strain TWAR. Clin. Infect. Dis., 15: 757-63, 1992.
12. Hadgu, A. The discrepancy in discrepant analysis. Lancet, 348: 592-3, 1996.

13. Hallsworth, G.P. et al. Comparison of antigen detection, polymerase chain reation and culture for detection of Chlamydia trachomatis in genital infection. Pathol., 27: 1687I, 1995.

14. Hall, S.G. Chlamydia trachomatis: update on laboratory diagnosis. Check sample. Am. Soc. Clin. Pathol., 40(4): 49-61, 1997.

15. Hillis, D.S. et al. Screening for Chlamydia: a key to the prevention of pelvic inflammatory disease. N. Engl. J. Med., 334(2I): |399-40|, 1996.

16. Hitchcock, P.J. Future directions of chlamydial research. In: Chlamydia intracellular biology pathogenesis, and immunity. Washington: ASM, 1999. Cap. 10, p. 297-311.

17. Howell, M.R. et al. Screening for Chlamydia trachomatis in asymptomatic women attending family planning clinics: a cost-effectiveness analysis of three strategies. Ann. Intern Med., 128(4): 277-84, 1998.

18. Kellogg, A. et al. Improved PCR detection of Chlamydia trachomatis by using an altered method of specimen transport and high-quality endocervical specimens. J. Clin. Microbiol., 33(I 0): 2765-7, 1995.

19. Kjaer, H.O. et al. Recurrence of urogenital Chlamydia trachomatis infection evaluated by mailed samples obtained at home: 24 weeks prospective follow-up study. Sex. Transm. Infect. 76: 169-72, 2000.

20. Kritski, L.A. et al. Reação em cadeia da polimerase (RCP/PCR) aplicada ao diagnóstico de tuberculose. J. Pneumol., 23(I): 33-42, 1997.

21. Laga, M.A. et al. Non-ulcerative sexually transmitted diseases a risk factors for HIV transmission in women: results from a cohort study. Aids, 7: 95-102, 1993.

22. Lan, J. et al. Direct detection and genotyping of Ct in cervica scrapes by using PCR and restriction fragment length polymorphism analysis. J. Clin. Microbiol., 3 I (5): I060-5, 1993. 
23. Lebar, D.W. Keeping up with new technology: new approaches to diagnosis of Chlamydia infection. Clin. Chem., 42(2): 80812, 1996.

24. Mahony, J. et al. Urine specimens from pregnant and nonpregnant women inhibitory to amplification of Chlamydia trachomatis nucleic acid by PCR, ligase chain reaction and transcriptase-mediated amplification: identification of urinary substances associated with inhibition and removal of inhibitory activity. J. Clin. Microbiol., 36(I I): 3122-6, 1998.

25. McCormack, M.W. et al. Urethrites in principles and practice of infectious diseases. 4.ed. Nova York: Churchill Livingstone, 1995, p. 1063-74.

26. Morré, S.A. et al. Serotyping and genotyping of genital Chlamydia trachomatis isolates reveal variants of serovars $\mathrm{Ba}, \mathrm{G}$ and J as confirmed by nucleotide sequence analysis. J. Clin. Microbiol., 36(2): 345-5I, 1998.

27. Morré, S.A. et al. Analysis of genetic heterogeneity in Chlamydia trachomatis clinical isolates of serovars D, E and $F$ by amplified fragment lenght polymorphism. J. Clin. Microbiol., 36(9): 3463-6, 2000.

28. Newhall, J.W. et al. Head-to-head evaluation of five Chlamydia tests relative to a quality-assured culture standard. J. Clin. Microbiol., 37(3): 681-5, 1999.

29. Ossewarde, J.M. et al. Development and clinical evaluation of a polymerase chain reaction test for detection of Chlamydia trachomatis. J. Clin. Microbiol., 30(8): 21 22-8, 1992.

30. Pedersen, N.L. et al. High-resolution genotyping of Chlamydia trachomatis from recurrent urogenital infections. J. Clin. Microbiol., 30(8): 3068-7I, 2000.

31. Peeling, R.W. et al. Antibody to chlamydial hsp60 predicts an increase risk for chlamydial pelvic inflammatory disease. J. Infect. Dis., I 75(5): I I53-8, 1997.

32. Puolakkainen, M. et al. Comparison of performances of two commercially available tests, a PCR assay and a ligase chain reaction test, in detection of urogenital Chlamydia trachomatis infection. J. Clin. Microbiol., 36(6): I489-93, 1998.
33. Quinn, T.C. et al. Epidemiologic and microbiologic correlates of Chlamydia trachomatis infection in sexual partnerships. Jama, 276(21): 1737-42, 1996.

34. Schachter, J. Infection and disease epidemiolgy. In: Chlamydia intracellular biology, pathogenesis and immunity. Washington: ASM, 1999. Cap. 6, p. I39-69.

35. Schachter, J. \& Stamm, W.E. Chlamydia. In: Manual of clinical microbiology. 7.ed. Washington, D.C.: ASM Press, 1999, p. 795-806.

36. Scholes, D.S. et al. Prevention of pelvic inflammatory disease by screnning for cervical Chlamydia infection. N. Engl. J. Med., 334: 1362-66, 1996.

37. Stary, A. et al. Detection of Chlamydia trachomatis in urethral and urine samples from symptomatic and asymptomatic male patients by polymerase chain reaction. Eur. J. Clin. Microbiol. Infect. Dis., 15(6): 465-7I, 1996.

38. Toye, B. et al. Association between antibody to the chlamydial heat-shock protein and tubal infertility. JID, 168: 1236-40, 1993.

39. Toye, B. et al. Inhibition of PCR in genital and urine specimens submitted for Chlamydia trachomatis testing. J. Clin. Microbiol., 36(8): 2356-58, 1998.

40. Valassina, M. et al. Detection by multiplex polymerase chain reaction and typing of Chlamydia trachomatis isolates. FEMS Microbiol. Let., 130: 205-10, 1995.

4I. Vogels, W.H.M.; Van Voorst, P.C. \& Schroder, F.P. Chlamydia trachomatis infection in a high-risk population: comparison of polymerase chain reaction and cell culture for diagnosis and follow-up. J. Clin. Microbiol., 3 I (5): I I03-07, 1993.

42.Warford, A. et al. Laboratory diagnosis of Chlamydia trachomatis infection. In: Cumitech. Washington, D.C.: ASM Press, 1999, v.19A, p. 2-18.

43.Wangs, S.P. et al. A simplified method of immunological typing of trachoma-inclusion conjunctivitis-lymphogranuloma venereum organisms. Infect. Immun., 7: 356-60, 1973.

44. Weinstock, H.M.D. et al. Chlamydia trachomatis infections. In: Sexually transmitted diseases in the Aids era: part II. Infect. Dis. Clin. N.Am., 8(4): 797-819, 1994. 